\title{
Kainic Acid-Induced Seizures Enhance Dentate Gyrus Inhibition by Downregulation of GABA Receptors $_{B}$
}

\author{
Kurt Z. Haas, ${ }^{1}$ Ellen F. Sperber, ${ }^{2}$ Solomon L. Moshé, ${ }^{1,2,3}$ and Patric K. Stanton ${ }^{1,2}$ \\ Departments of ${ }^{1}$ Neuroscience, ${ }^{2}$ Neurology, and ${ }^{3}$ Pediatrics, Albert Einstein College of Medicine, Bronx, \\ New York 10461-1602
}

\begin{abstract}
Seizures cause a persistent enhancement in dentate synaptic inhibition concurrent with, and possibly compensatory for, seizure-induced hippocampal hyperexcitability. To study this phenomenon, we evoked status epilepticus in rats with systemic kainic acid (KA), and 2 weeks later assessed granule cell inhibition with paired-pulse stimulation of the perforant path (PP) in vitro. Controls demonstrated three components of paired-pulse inhibition: early inhibition (10-30 msec), intermediate facilitation (30-120 msec), and late inhibition (120 msec to $120 \mathrm{sec}$ ). After seizures, inhibition in all components was enhanced significantly. The $\mathrm{GABA}_{\mathrm{A}}$ antagonist bicuculline blocked only early enhanced inhibition, demonstrating that both $\mathrm{GABA}_{A}$ and $\mathrm{GABA}_{\mathrm{B}}$ postsynaptic receptors contribute to seizure-induced enhanced inhibition. In controls, the $G_{A B A}$ antagonist CGP 35348 increased both $\mathrm{GABA}_{A}$ and $\mathrm{GABA}_{\mathrm{B}}$ responses in granule cells, suggesting that CGP 35348 acts presynaptically, blocking receptors that suppress GABA release. In contrast, slices from KA-treated rats were markedly
\end{abstract}

less sensitive to CGP 35348. To test the hypothesis that GABA receptors regulating GABA release are downregulated after seizures, we measured paired-pulse suppression of recurrent IPSPs, or disinhibition, using mossy fiber stimuli. Early disinhibition $(<200 \mathrm{msec})$ was reduced after seizures, whereas late disinhibition remained intact. CGP 35348 blocked the early component of disinhibition in controls and, to a lesser extent, reduced disinhibition in KA slices. However, paired monosynaptic IPSPs recorded intracellularly showed no difference in disinhibition between groups. Our findings indicate that seizure-induced enhancement in dentate inhibition is caused, at least in part, by reduced $\mathrm{GABA}_{\mathrm{B}}$ function in the polysynaptic recurrent inhibitory circuit, resulting in reduced disinhibition and heightened GABA release.

Key words: hippocampus; dentate gyrus; paired-pulse inhibition; $G A B A_{B}$; disinhibition; presynaptic; autoreceptors; kainic acid; bicuculline; CGP 35348; epilepsy; seizures
Neuronal alterations produced by seizures have been implicated in promoting cellular hyperexcitability and seizure propagation. In animal models of epilepsy, including kainic acid (KA)-induced status epilepticus (Holmes and Thompson, 1988; Stafstrom et al., 1992; Lothman and Bertram, 1993) and kindling (Goddard et al., 1969; Wong and Moshé, 1987; Holmes et al., 1993), seizures alter the brain, increasing susceptibility to subsequent epileptogenic stimuli. Seizure-induced changes that contribute to this heightened excitability include enhanced NMDA receptor function (Mody et al., 1988; Martin et al., 1992; Kohr et al., 1993; Kohr and Mody, 1994), reduced inhibition in CA1 (King et al., 1985; Kapur et al., 1989) and CA3 (Zhao and Leung, 1992), death of hilar cells that normally excite recurrent inhibitory interneurons (Sloviter, 1987; Cavazos and Sutula, 1990), axonal sprouting, and formation of aberrant excitatory synapses (Sutula, 1988).

In contrast to these persistent changes that promote hyperexcitability, inhibition of dentate gyrus granule cells is lost only transiently during and immediately after seizures (Maru and God-

Received Feb. 5, 1996; revised April 12, 1996; accepted April 16, 1996.

This work was supported in part by National Institutes of Health Training Grant T32DK07513 (K.Z.H.), the Klingenstein Foundation, the Office of Naval Research (P.K.S.), and National Institute of Neurological Diseases and Stroke Research Grants NS-20253 (S.L.M.) and NS-30387 (E.F.S.). Data in this paper are from a thesis to be submitted in partial fulfillment of the requirements for the degree of Doctorate of Philosophy in the Sue Golding Graduate Division of Medical Sciences, Albert Einstein College of Medicine, Yeshiva University.

Correspondence should be addressed to Kurt Z. Haas, Albert Einstein College of Medicine, Laboratory of Developmental Epilepsy, 316 Kennedy Center, 1410 Pelham Parkway South, Bronx, NY 10461-1602.

Copyright (C) 1996 Society for Neuroscience $0270-6474 / 96 / 164250-11 \$ 05.00 / 0$ dard, 1987; Milgram et al., 1991; Spiller and Racine, 1994). Within $24 \mathrm{hr}$, PP-evoked inhibition of granule neurons recovers to levels higher than those preceding KA administration (Milgram et al., 1991) or kindled stimulation (Tuff et al., 1983; King et al., 1985; Oliver and Miller, 1985; de Jonge and Racine, 1987; Maru and Goddard, 1987; Gilbert, 1991; Milgram et al., 1995), although this inhibition may be subject to more rapid fatigue (Sloviter, 1992; Buhl et al., 1996). Little is known about the underlying mechanisms or the functional role of this enhanced inhibition. The concurrent expression of increased dentate inhibition and hyperexcitability throughout the hippocampus (King et al., 1985; Cronin et al., 1992; Zhao and Leung, 1992; Bekenstein et al., 1993) suggests that enhanced inhibition may be a compensatory mechanism to suppress the spread of seizure activity.

Although studies have indicated an increase of late $\mathrm{Cl}^{-}$independent synaptic potentials (Oliver and Miller, 1985), $\mathrm{GABA}_{\mathrm{A}}$ receptor number- (Otis et al., 1994) or both postsynaptic $\mathrm{GABA}_{\mathrm{A}}$ and $\mathrm{GABA}_{\mathrm{B}}$ receptor response- (Sperber, 1991; de Jonge and Racine, 1987; Gilbert, 1991) enhanced paired-pulse inhibition might not be mediated solely by postsynaptic mechanisms, because there is a complex presynaptic regulation of inhibitory transmission. Repeated stimuli produce a decrease in inhibitory postsynaptic potential (IPSP) amplitude, a phenomenon called disinhibition, produced in large part by activation of presynaptic $\mathrm{GABA}_{\mathrm{B}}$ receptors (Thompson, 1992; Lambert and Wilson, 1993; Pitler and Alger, 1994; Pearce, 1995). GABA G $_{\mathrm{B}}$ receptors that suppress neurotransmitter release have been found on presynaptic terminals of both GABAergic (Davies and Col- 
lingridge, 1993; Mott et al., 1993) and glutamatergic (Harrison et al., 1990; Scanziani et al., 1992; Davies et al., 1993) neurons in the hippocampus. Therefore, inhibition of granule neurons also could be enhanced either by raising the excitatory drive on inhibitory interneurons (Collins et al., 1982) or by reducing $\mathrm{GABA}_{\mathrm{B}}$ receptor-mediated suppression of GABA release from inhibitory terminals (Davies et al., 1990; Mott et al., 1993).

In the dentate gyrus of in vitro hippocampal slices, we have used selective antagonists to remove $\mathrm{GABA}_{\mathrm{A}}$ or $\mathrm{GABA}_{\mathrm{B}}$ inhibition to determine which receptor populations show seizure-induced alterations. In addition, extracellular and intracellular recordings from dentate granule neurons were used to examine frequencydependent disinhibition of IPSPs in the recurrent inhibitory pathway. Our results demonstrate that although both postsynaptic $\mathrm{GABA}_{\mathrm{A}}$ and $\mathrm{GABA}_{\mathrm{B}}$ responses are enhanced by seizures, the underlying mechanism is a decreased $\mathrm{GABA}_{\mathrm{B}}$ receptor-mediated suppression of presynaptic GABA release. Portions of these results have been presented elsewhere (Sperber et al., 1991; Haas et al., 1994).

\section{MATERIALS AND METHODS}

$K A$ status epilepticus. Seizures were induced in 60-d-old, male SpragueDawley rats (Taconic Farms, NY) by systemic KA injection $(15 \mathrm{mg} / \mathrm{kg}$, i.p.) (K 0250, Sigma, St. Louis, MO). Rats were monitored for seizure behavior for $24 \mathrm{hr}$ after injection. Only rats displaying severe status epilepticus, defined as continuous tonic-clonic seizure behavior for at least $30 \mathrm{~min}$, were used in this study.

Electrophysiology. Two weeks after exposure to KA status epilepticus, KA-treated rats $(n=28)$ and age-matched controls $(n=26)$ were decapitated under deep ether anesthesia and the brains rapidly removed. The hippocampus plus attached entorhinal cortex were dissected out, submerged in a reservoir containing chilled artificial CSF (ACSF), and sliced transversely with a vibratome (400 $\mu$ m thick) (Ted Pella, Reading, CA). Slices were transferred to an interface perfusion chamber (Haas et al., 1979) and bathed continuously with ACSF containing (in mM): $\mathrm{NaCl}$ $126, \mathrm{KCl} 5, \mathrm{CaCl}_{2} 2, \mathrm{MgCl}_{2} 2, \mathrm{NaH}_{2} \mathrm{PO}_{4} 1.25, \mathrm{NaHCO}_{3} 26$, D-glucose 10, $\mathrm{pH} 7.2,32-34^{\circ} \mathrm{C}$. Slices were incubated for at least $30 \mathrm{~min}$ before recording. For extracellular recording of field potentials, glass microelectrodes (microfilament capillary $1.2 \mathrm{~mm}$ outer diameter; 5-10 M $\Omega$ ) (A-M Systems) filled with $\mathrm{NaCl}(2 \mathrm{M})$ were placed in the granule cell body layer (stratum granulosum) of the suprapyramidal blade of the dentate gyrus. Bipolar, twisted tungsten stimulating electrodes (tip distance $50 \mu \mathrm{m}$ ) (Frederick Haer) were placed in the perforant path (PP) for orthodromic activation of granule cells and at the CA3-hilar border to stimulate mossy fibers antidromically, and stimuli were applied as DC square pulses (20-400 $\mu \mathrm{A}, 100 \mu \mathrm{sec}$ duration). Extracellular population spikes were recorded with an Axoclamp-2A amplifier, and data were digitized and analyzed on an IBM PC-AT. To block GABA receptors, either the GABA $_{\mathrm{A}}$ antagonist bicuculline $(10 \mu \mathrm{M})$ (Tocris Cookson, St. Louis) or the $\mathrm{GABA}_{\mathrm{B}}$ antagonist 3-aminopropyl-diethoxymethyl-phosphinic acid, CGP 35348 (Olpe et al., 1990), $400 \mu \mathrm{M}$ ) (a generous gift from Ciba-Geigy, Basel, Switzerland) was bath applied for $1 \mathrm{hr}$ before electrophysiological recording.

Intracellular recordings from granule cells were made with glass electrodes filled with $3 \mathrm{M} \mathrm{K}^{+}$acetate $(120-170 \mathrm{M} \Omega)$. Stimulating electrodes were placed in the stratum granulosum proximal to the recording electrode to activate interneurons directly and evoke monosynaptic IPSPs. Excitatory amino acid neurotransmission was blocked with the AMPA receptor antagonist 6-cyano-7-nitroquinoxaline-2,3-dione [CNXQ (10 $\mu \mathrm{M})$ ] plus the NMDA receptor antagonist D-APV $(40 \mu \mathrm{M})$, bath applied for $30 \mathrm{~min}$ before recording. Intracellular data were filtered at $3 \mathrm{kHz}$ and sampled at $20 \mathrm{kHz}$. CNQX and D-APV were purchased from Tocris Neuramin (Bristol, England).

Stimulation paradigms. The amplitude and time course of feedforward and feedback inhibition of dentate granule cells were assessed with paired-pulse stimulation of the PP. PP stimulus evoked EPSPs, and action potentials (population spikes) were recorded extracellularly in the stratum granulosum (see Fig. $2 A$, Control PS1, $10 \mathrm{msec}$ ). Two identical stimuli were delivered with interstimulus intervals (ISIs) ranging from 10 msec to $9 \mathrm{sec}$. Stimulus intensities were chosen such that the first evoked population spike was $\sim 75 \%$ of maximum. Paired-pulse inhibition was measured as the ratio of the second, test, population spike (PS2) amplitude to the amplitude of the first, conditioning, population spike (PS1). A decrease in the test spike amplitude compared with the conditioning spike indicated paired-pulse inhibition (Fig. 2A, Control, $10 \mathrm{msec}$ ), whereas a relative increase represented facilitation (Fig. $2 \mathrm{~A}$, Control, 50 $\mathrm{msec}$ ). No paired-pulse effects were observed with intervals longer than $10 \mathrm{sec}$, so the time between pairs of stimuli was maintained at $20 \mathrm{sec}$ to avoid interference between trials.

Disinhibition of recurrent inhibition, the decrease in IPSP amplitude with repeated stimuli, was measured using paired-pulse stimulation of mossy fibers. Stimulation of mossy fibers at the hilar-CA3 border evoked a negative-going antidromic population action potential without an EPSP (see Fig. 5A) and activated feedback inhibition. Because pure IPSPs cannot be directly recorded extracellularly (Brunner and Misgeld, 1993), IPSP strength was inferred from the decrease in amplitude that an antidromic mossy fiber stimulus produced on a subsequent orthodromic PP-evoked population spike (see Fig. 5A, compare amplitude of the PP response alone, left, to the PP response in the $M F-P P$ pair, right). Mossy fiber and PP stimulus intensities were chosen such that the mossy fiberevoked recurrent IPSP inhibited the orthodromic population spike by $50 \%$ at an interpulse interval of $5 \mathrm{msec}$. To produce disinhibition of recurrent inhibition, paired mossy fiber stimuli were delivered with ISIs ranging from $10 \mathrm{msec}$ to $9 \mathrm{sec}$, with the second mossy fiber stimulus followed $5 \mathrm{msec}$ later by a test orthodromic stimulus to the PP (see Fig. $5 B$ ). The decrease in the second mossy fiber-evoked IPSP was apparent as an increase in amplitude of the test PP-evoked population spike (Fig. $5 B$ ) compared with inhibition produced by a single MF stimulation (Fig. $5 A$, $M F-P P)$.

In intracellular recordings from granule neurons, pure monosynaptic IPSPs were evoked by proximal stimulation of the stratum granulosum in the presence of CNQX $(10 \mu \mathrm{M})$ and D-APV $(40 \mu \mathrm{M})$. Disinhibition of monosynaptic IPSPs was examined using paired-pulse stimulations in the stratum granulosum. Intervals between stimulations ranged from 30 to 900 msec. Intracellular recordings were only made from cells with resting membrane potentials more hyperpolarized than $-60 \mathrm{mV}$, input resistances $>30 \mathrm{M} \Omega$, and overshooting action potentials.

Data from paired-pulse experiments were compared using a one-way ANOVA. Statistical significance of intracellular measurements were determined with the Student's $t$ test for unpaired data.

Histology. Histological examination for cell loss and synaptic reorganization were performed on a subset of the rats used for electrophysiological studies ( $n=5 \mathrm{KA}$ treated; 5 controls). Brains were removed and bisected, with half used for paired-pulse electrophysiology as described above. The other half was prepared for histological examination using the Timm silver sulfide stain for mossy fiber terminals and thionin stain for neuronal loss.

The hemisections were immersed in a $0.4 \%$ sodium sulfide solution for 20 min followed by overnight fixation in a $1 \%$ paraformaldehyde and $1.25 \%$ glutaraldehyde solution (Tauck and Nadler, 1985), followed by 24 $\mathrm{hr}$ in fixation solution with $30 \%$ sucrose. Brains were frozen rapidly with methylbutane $\left(-35^{\circ} \mathrm{C}\right)$ and cut horizontally in a cryostat $(30 \mu \mathrm{m} \mathrm{sec}-$ tions). The sections were developed in the dark for $45-60 \mathrm{~min}$ in a solution of $20 \%(\mathrm{w} / \mathrm{v})$ gum arabic, $5.6 \%(\mathrm{w} / \mathrm{v})$ hydroquinone, and citric acid/sodium citrate buffer with a solution of $17 \%$ silver nitrate. After staining, the sections were dehydrated in alcohol. Alternate sections were hydrated and stained with thionin. The sections then were dehydrated in alcohol and examined microscopically.

\section{RESULTS}

\section{KA-induced seizures}

60-d-old rats received a single, systemic, intraperitoneal injection of KA $(15 \mathrm{mg} / \mathrm{kg})$, which produced severe tonic-clonic seizures and a high mortality rate $(40 \%)$. Intermittent seizure behavior and mouth and forelimb clonus developed within 30-60 min after injection, and then progressed to continuous forelimb clonus, with rearing and falling lasting from $30 \mathrm{~min}$ to $>1 \mathrm{hr}$. After termination of status, rats continued to express sporadic, short-duration bouts of seizure behavior for $24 \mathrm{hr}$. All rats examined histologically 2 weeks after seizures $(n=5)$ showed dense supragranular Timm staining (Fig. $1 A, K A$, arrows), indicative of mossy fiber sprouting and aberrant synaptogenesis (Tauck and Nadler, 1985; Sperber et al., 1991), and loss of CA3 pyramidal cells with thionin staining 


\section{Control}

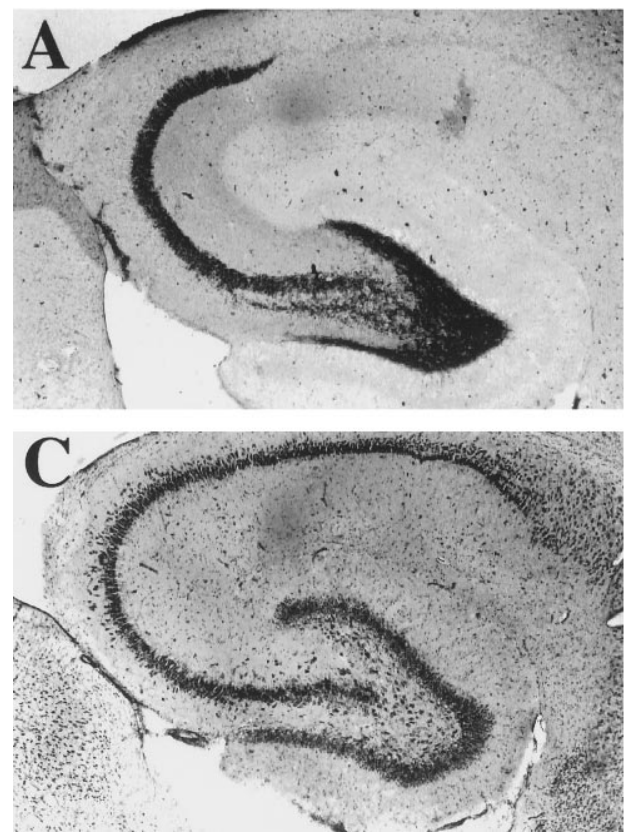

KA

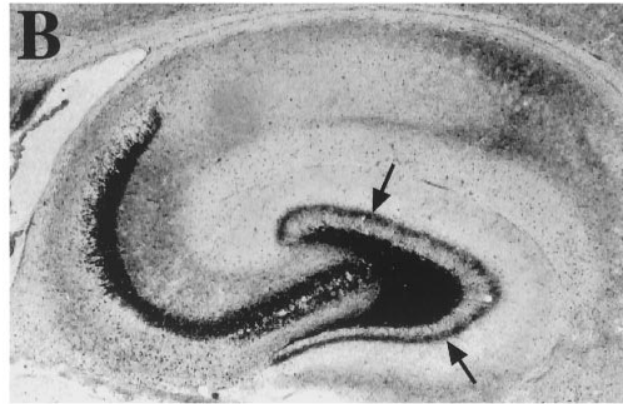

Figure 1. Synaptic reorganization and cell loss 2 weeks after KA-induced status epilepticus $(K A)$. $A, B$, Timm silver sulfide stain for mossy fiber axonal terminals. In controls $(A)$, positive Timm staining (dark granular stain) demonstrates granule cell axonal termination in the hilus and proximal dendrites of CA3 pyramidal cells. Two weeks after KA-induced status epilepticus $(B)$, aberrant Timm staining (arrows) is evident in supragranular layers throughout the dentate crests. $C, D$, Thionin staining shows cell bodies of dentate granule cells and pyramidal neurons of the hippocampus $(C)$. KA-treated rats $(D)$ have marked cell loss in area CA 3 and the hilus 2 weeks after seizures (arrows).
(Fig. 1B). Alterations in Timm staining and cell loss were consistent in all rats examined, and seizure severity among all KAtreated rats was similar.

\section{KA status epilepticus produces a persistent increase in perforant path inhibition}

PP stimulation evoked a positive-going EPSP and a superimposed negative-going population action potential, or spike, in field recordings from the stratum granulosum (Fig. $2 A$ ). PP stimulation also activated inhibitory interneurons mediating feedforward inhibition, whereas granule cell discharge evoked recurrent inhibition. Once activated, both feedforward and feedback inhibition suppressed granule cell firing, producing paired-pulse inhibition.

Paired-pulse stimulation of the PP in hippocampal slices from control rats showed a triphasic profile of granule cell inhibition (Fig. $2 B$, open circles, each point $=$ mean \pm SEM). A rapidly activating, short-latency inhibition was present at ISIs ranging from 10 to $30 \mathrm{msec}$ (Fig. 2B, Control, $10 \mathrm{msec}$ ). ISIs between 30 and $120 \mathrm{msec}$ caused facilitation of the second population spike (Fig. 2A, Control, $50 \mathrm{msec}$ ), whereas longer ISIs (120 msec to 6 sec) produced a late-activating, long-lasting inhibition (Fig. $2 A$, Control, $200 \mathrm{msec}$ ). The time courses of early and late pairedpulse inhibition are consistent with those of $\mathrm{GABA}_{\mathrm{A}}$ receptorand $\mathrm{GABA}_{\mathrm{B}}$ receptor-mediated IPSPs, respectively.

Two weeks after KA-induced seizures, slices from these rats showed a significant increase in paired-pulse inhibition over ISIs ranging from 10 to $500 \mathrm{msec}$, a duration that encompasses both early and late inhibition, as well as facilitation (Fig. 2B, closed circles, asterisks, $p<0.05$, one-way ANOVA compared with controls). This apparent enhancement of inhibition completely eliminated paired-pulse facilitation in slices from KA-treated rats (Fig. $2 A, K A, 50 \mathrm{msec}$ ). Electrophysiological responses from KA-treated rats otherwise appeared normal; in particular, multiple population spikes were not evoked either by PP or mossy fiber stimulation.

\section{Role of $\mathrm{GABA}_{A}$ and $\mathrm{GABA}_{B}$ receptors in seizure-enhanced inhibition}

The $\mathrm{GABA}_{\mathrm{A}}$ receptor antagonist bicuculline $(10 \mu \mathrm{M})$ completely blocked early inhibition in slices from both control and KA-treated rats (Fig. 3). Blockade of $\mathrm{GABA}_{\mathrm{A}}$ receptor-mediated inhibition by bicuculline produced multiple spiking in response to PP stimulation and unmasked paired-pulse facilitation at short ISIs in both groups. In bicuculline, there was no longer any significant difference in paired-pulse inhibition in control and KA slices at short ISIs (Fig. 3) (ISI $<70 \mathrm{msec}$ ). In contrast, late $\mathrm{GABA}_{\mathrm{B}}$ receptor-mediated inhibition was unaltered by bicuculline (compare ISIs $>90 \mathrm{msec}$ in Figs. 3 and $2 B$ ), and the significant difference between slices from control and KA rats was still present at longer ISIs, 70-400 msec (Fig. 3, asterisks, $p<0.05$ ). These results indicate that enhanced early inhibition is caused by increased $\mathrm{GABA}_{\mathrm{A}}$ receptor activation, whereas KA-induced enhancement of late inhibition is mediated through enhanced $\mathrm{GABA}_{\mathrm{B}}$ receptor function. Therefore, enhanced inhibition after KA status is not attributable to the selective enhancement of activation of only one subtype of postsynaptic GABA receptor.

\section{The GABA $A_{B}$ receptor antagonist CGP 35348 acts as a selective blocker of presynaptic $\mathrm{GABA}_{B}$ receptors}

To determine the contribution of $\mathrm{GABA}_{\mathrm{B}}$ receptors to control paired-pulse inhibition and enhanced inhibition in KA-treated rats, the selective $\mathrm{GABA}_{\mathrm{B}}$ antagonist CGP 35348 was bath applied to slices. CGP $35348(400 \mu \mathrm{M})$ produced a significant increase in control-slice paired-pulse inhibition at ISIs ranging from 10 to $600 \mathrm{msec}$ (Fig. 4 A, closed circles, asterisks, $p<0.05$ compared with controls without CGP 35348, open circles). The late paired-pulse inhibitory component was not decreased by CGP 35348 , as would be expected from a postsynaptic $\mathrm{GABA}_{\mathrm{B}}$ receptor antagonist. Thus, the drug-induced enhancement of both $\mathrm{GABA}_{\mathrm{A}}$ and $\mathrm{GABA}_{\mathrm{B}}$ postsynaptic responses is consistent with selective blockade of presynaptic $\mathrm{GABA}_{\mathrm{B}}$ receptors, which normally act to suppress GABA release. 


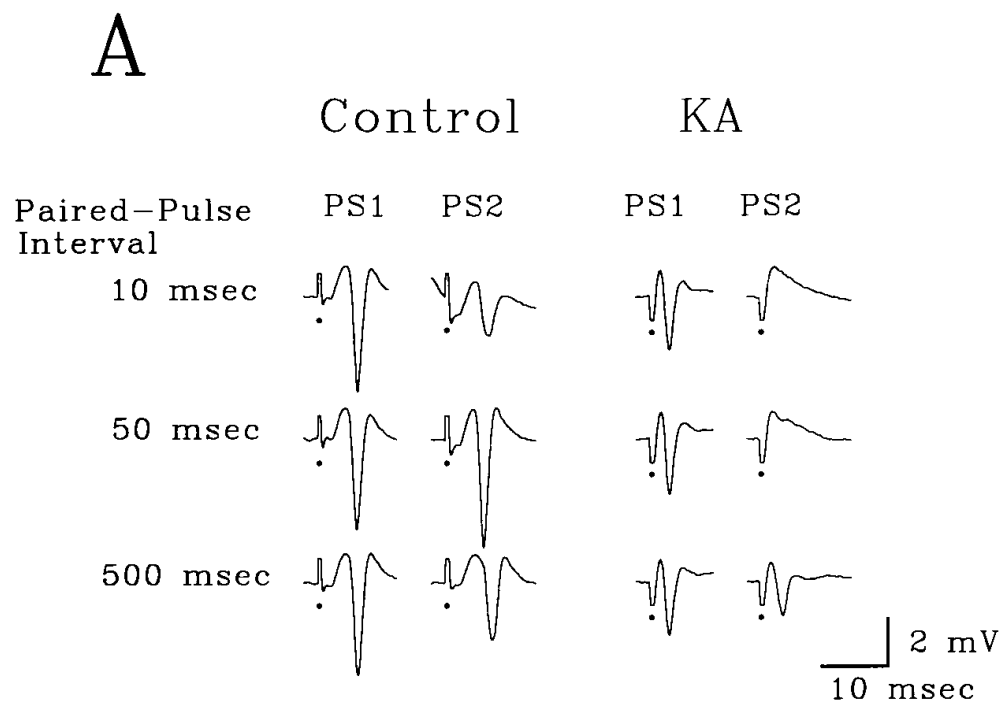

B

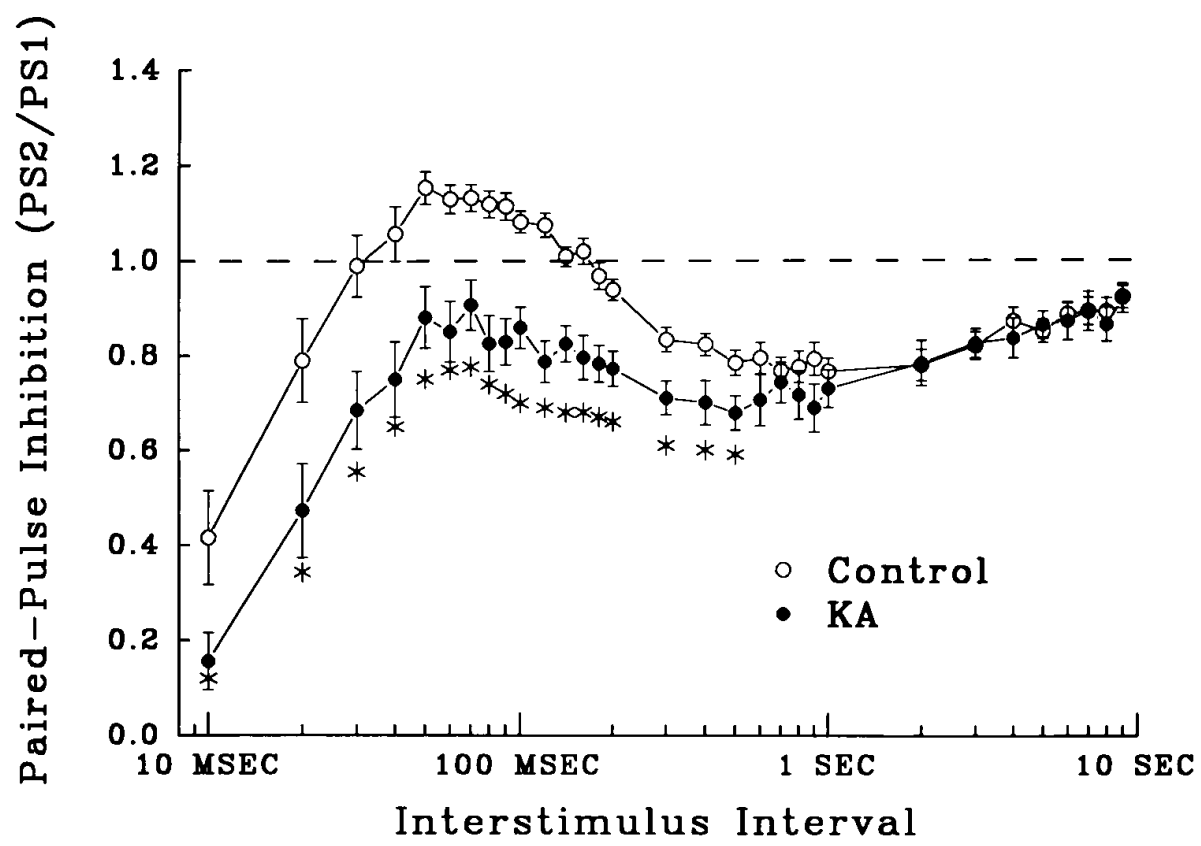

Figure 2. Enhanced paired-pulse inhibition in hippocampal slices from KA-treated rats 2 weeks after seizures. $A$, Field population spikes $(P S)$ recorded in the stratum granulosum elicited by pairs of PP stimulation. The three ISIs shown demonstrate paired-pulse early inhibition $(10 \mathrm{msec})$, intermediate facilitation $(50 \mathrm{msec})$, and late inhibition (500 $\mathrm{msec}$ ) in control slices. Enhanced inhibition after KA status is apparent as a marked decrease in amplitude of the second response (PS2), compared with the first (PS1), and a complete loss of paired-pulse facilitation. (Closed circles denote truncated stimulus artifacts.) $B$, Paired-pulse profile from control (open circles) and KA-treated rats 2 weeks after seizures (closed circles). The percent change in the second population spike (PS2) amplitude compared with the first (PS1) (mean $\pm \mathrm{SEM}$ ) is presented at each interstimulus interval tested. The dotted line marks no change in the amplitude of the second response compared with the first $(\mathrm{PS} 2=\mathrm{PS} 1)$. Points above the dotted line represent facilitation, whereas values below indicate inhibition. Control slices $(n=29)$ showed early (10-30 msec) and late (120$6000 \mathrm{msec}$ ) paired-pulse inhibition, separated by paired-pulse facilitation (30-120 msec). In contrast, hippocampal slices from KA-treated rats $(n=21)$ showed enhanced paired-pulse inhibition at intervals from 10 to $500 \mathrm{msec}$ (asterisks, one-way ANOVA, $p<$ 0.05 , compared with controls).
The magnitude and time course of CGP 35348-induced increases in inhibition in control slices were very similar to changes produced by KA seizures (compare Fig. $2 B$, closed circles with Fig. $4 A$, closed circles). Furthermore, in marked contrast to controls, CGP 35348 was largely ineffective on slices from KA-treated rats (Fig. $4 B$ ). The GABA $_{\mathrm{B}}$ antagonist produced an increase in inhibition only at short ISIs $(10-30 \mathrm{msec})$ (Fig. 4B, asterisks, $p<0.05)$. These data suggest that CGP 35348- and KA status-mediated enhancement of inhibition might be produced through the same mechanism, a functional downregulation of presynaptic $\mathrm{GABA}_{\mathrm{B}}$ receptors.

\section{Measuring recurrent disinhibition in control and KA-treated rats}

Extracellular field potential measurements of paired-pulse depression of recurrent IPSPs were carried out to assess directly presynaptic $\mathrm{GABA}_{\mathrm{B}}$ receptor function. Disinhibition, the decrease in IPSP strength with repeated stimuli, has been shown to be mediated, in large part, by the activation of presynaptic $\mathrm{GABA}_{\mathrm{B}}$ receptors (Deisz and Prince, 1989; Thompson and Gahwiler, 1989; Brucato et al., 1992; Mott et al., 1993). Figure 5C illustrates the profile of disinhibition produced by paired mossy fiber stimuli in control hippocampal slices. Pairs of mossy fiber stimuli, which evoked recurrent inhibition of granule cells, increased or decreased the amount of inhibition induced by the second stimulus of the pair, depending on the ISI. This distribution can be measured by the amount of inhibition produced by the pair on a third, PP-evoked response. In control rats, at short ISIs (10-20 msec), the amount of recurrent inhibition was increased, probably because of the summation of $\mathrm{GABA}_{\mathrm{A}}$ IPSPs (Fig. $5 C$, open circles). ISIs between $50 \mathrm{msec}$ and $3 \mathrm{sec}$ produced a decrease 
Figure 3. The $\mathrm{GABA}_{\mathrm{A}}$ receptor antagonist bicuculline $(10 \mu \mathrm{M})$ blocked early paired-pulse inhibition in both control slices (open circles, $n=20$ ) and slices from KA-treated rats (closed circles, $n=$ 30) (mean \pm SEM PS2/PS1. The blockade of early inhibition unmasked equal paired-pulse facilitation in both groups, but late, $\mathrm{GABA}_{\mathrm{B}}$ receptor-mediated inhibition in slices from KA-treated rats still was enhanced significantly compared with controls (asterisks, $p<0.05$, one-way ANOVA; points with no error bars had SEMs smaller than symbols).

in recurrent inhibition, evident by an increase in orthodromic population spike (Fig. $5 B$ ). This disinhibition is thought to be attributable, in part, to activation of $\mathrm{GABA}_{\mathrm{B}}$ autoreceptors, which limit GABA release.

In comparison to controls, disinhibition was decreased significantly in slices from KA-treated rats (Fig. 5C, closed circles, asterisks, $p<0.05$, one-way ANOVA). ISIs between 30 and 180 msec failed to evoke a decrease in recurrent inhibition. Disinhibition was evoked by longer ISIs, $300 \mathrm{msec}$ to $3 \mathrm{sec}$, and in contrast to shorter intervals, the profiles of late disinhibition at these ISIs were not different in KA versus control slices. The reduction in disinhibition produced by KA seizures results in enhanced GABA release during paired stimuli and may explain enhanced PP paired-pulse inhibition.

\section{$\mathrm{GABA}_{\mathrm{B}}$ receptors contribute to recurrent disinhibition}

To assess the role of presynaptic $\mathrm{GABA}_{\mathrm{B}}$ receptors in pairedpulse IPSP disinhibition, we bath applied CGP 35348. Figure $6 A$ shows that in control slices, CGP $35348(400 \mu \mathrm{M})$ blocked disinhibition only at ISIs shorter than $200 \mathrm{msec}$ (closed circles, asterisks, $p<0.05$ ). Disinhibition at longer intervals was unaltered by the $\mathrm{GABA}_{\mathrm{B}}$ antagonist, suggesting that there are at least two components of disinhibition mediated by separate mechanisms. Similar to its effect on the orthodromic paired-pulse profile in controls (Fig. $4 A$ ), the blockade by CGP 35348 of control disinhibition looked very similar to the decrease in disinhibition seen in the absence of drug in slices from KA-treated rats. CGP 35348 still produced some additional depression of disinhibition in slices from KA-treated rats (Fig. $6 B$, asterisks, $p<0.05$ ). The percent decrease was markedly less than that seen in CGP 35348-treated controls, suggesting that KA seizures already had caused a functional downregulation of the contribution of presynaptic $\mathrm{GABA}_{\mathrm{B}}$ receptors to paired-pulse IPSP disinhibition.

\section{Disinhibition of monosynaptic IPSPs recorded intracellularly is not reduced by KA treatment}

Given the extracellular data described above, we recorded intracellularly in granule cells to examine directly disinhibition of

\section{- Control ( $10 \mu \mathrm{M}$ Bicuculline) - KA (10 $\mu \mathrm{M}$ Bicuculline)}



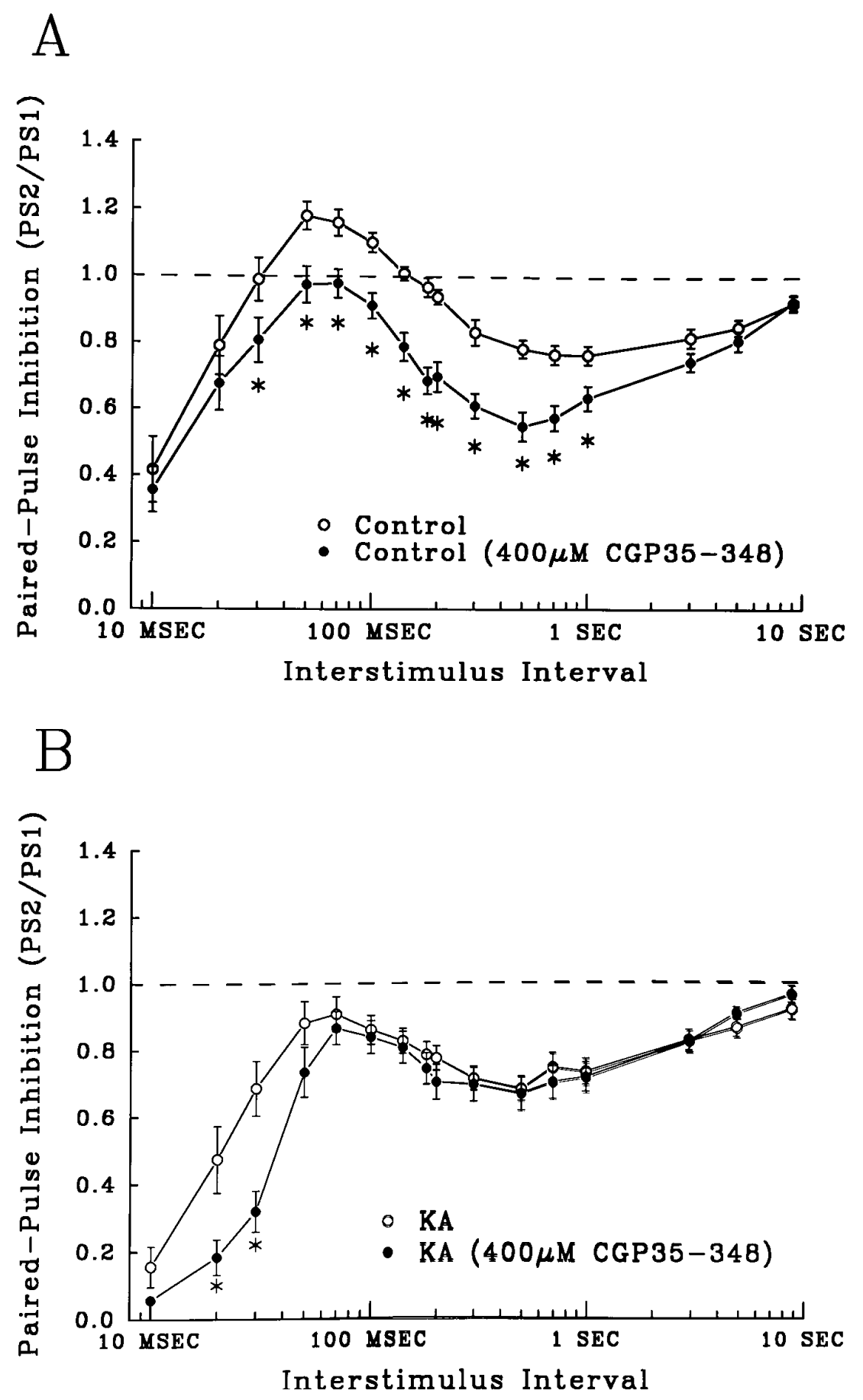

Figure 4. The $\mathrm{GABA}_{\mathrm{B}}$ receptor antagonist CGP 35348 acted as a blocker of presynaptic $\mathrm{GABA}_{\mathrm{B}}$ autoreceptors in control slices, but was largely ineffective in slices from KA-treated rats. $A$, CGP $35348(400 \mu \mathrm{M})$ increased early and late paired-pulse inhibition significantly in control slices at ISIs of $30 \mathrm{msec}$ to $1 \mathrm{sec}$. Open circles graph control paired-pulse profiles $(n=29)$, and closed circles are from control slices perfused with CGP 35348 (400 $\mu \mathrm{M})(n=26$, asterisks, $p<0.05$, compared with untreated controls). $B$, In slices from KA-treated rats, CGP 35348 enhanced only early inhibition, ISIs of 20-30 msec (closed circles $=$ CGP 35348 treated, $n=25$; open circles $=$ untreated, $n=21$; asterisks, $p<0.05$, compared with controls). In contrast to control slices, CGP 35348 had no significant effect on late paired-pulse inhibition after KA-induced seizures.

Goddard, 1987; Gilbert, 1991; Milgram et al., 1991; Spiller and Racine, 1994). In contrast, aberrant supragranular Timm staining requires at least $4 \mathrm{~d}$ to develop, increases in intensity over several weeks, and appears to be permanent (Cavazos et al., 1991; Mello et al., 1993; Okazaki et al., 1995). The new mossy fiber collaterals appear to terminate on granule neurons, not inhibitory basket cells (Represa et al., 1993; Okazaki et al., 1995), forming new excitatory feedback inputs to granule cells (Tauck and Nadler, 1985; Cronin et al., 1992). Indeed, enhanced granule cell inhibition might function to counter this new excitation directly. Cronin et al. (1992) have observed that dentate responses in slices from KA status rats appear normal in control solutions, but exhibited abnormal hyperactivity when GABAergic inhibition was blocked.
The rapid development of enhanced inhibition suggests that it may be independent of extensive anatomic alteration.

Results differ about whether seizures enhance early $\left[\mathrm{GABA}_{\mathrm{A}}\right.$ receptor-mediated inhibition (Milgram et al., 1991; Otis et al., 1994; Spiller and Racine, 1994)], late [GABA $_{\mathrm{B}}$ receptor-mediated inhibition (Oliver and Miller, 1985)], or both (Tuff et al., 1983; de Jonge and Racine, 1987; Gilbert, 1991; Sperber, 1991). Oliver and Miller (1985) found that kindling selectively enhances a $\mathrm{Cl}^{-}$. independent late component of paired-pulse inhibition, consistent with $\mathrm{GABA}_{\mathrm{B}}$ receptor enhancement, whereas Otis and Mody (1994) described a kindling-induced enhancement of postsynaptic $\mathrm{GABA}_{\mathrm{A}}$ receptor activation, possibly attributable to an increase in $\mathrm{GABA}_{\mathrm{A}}$ receptor number. In the present studies, we show that 
A
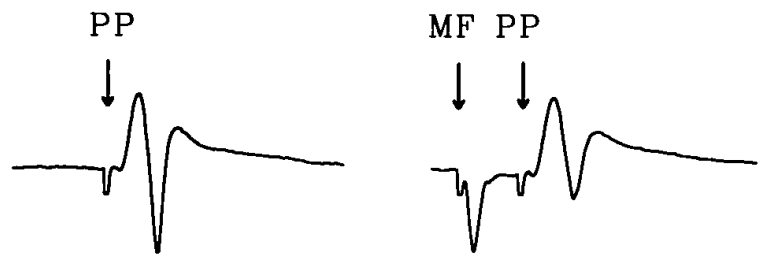

Figure 5. Recurrent inhibition on granule cells was reduced by paired mossy fiber stimulation. Disinhibition of recurrent inhibition was measured as a reduction in the inhibitory effect on a PP-evoked population spike. $A$, Field potentials evoked by orthodromic stimulation of the PP (PP) alone and an identical PP stimulation preceded by a mossy fiber stimulus $(M F)$ to illustrate mossy fiber-evoked inhibition of the population spike. The interval between the MF and PP stimuli was $5 \mathrm{msec}$, which produced a $50 \%$ reduction in the population spike amplitude. Stimulus artifacts have been truncated. $B$, Disinhibition of recurrent inhibition was produced with pairs of MF stimuli. Here, MF stimuli are separated by $200 \mathrm{msec}$, which reduces inhibition on the test population spike. Compare amplitude of the test PPevoked population spike with that in the MF-PP pair in $A$. Stimulus artifacts have been truncated. $C$, The time course of disinhibition of recurrent inhibition in slices from controls (open circles, $n=17$ ) versus KA-treated rats (closed circles, $n=20$ ). Plot is of the mean ratios \pm SEM of the amplitudes of the population spike in the MF-PP pair preceded by an initial MF stimulus (as in $B$ ) to the population spike in a MF-PP pair alone (as in $A$ ). Slices from KA-treated rats showed significantly reduced disinhibition at ISIs ranging from 30 to $120 \mathrm{msec}$ (asterisks, $p<0.05$, one-way ANOVA, compared with control slices).

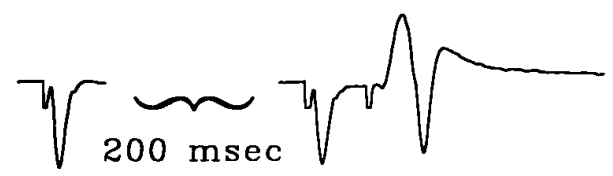

$2 \mathrm{mV}$

$10 \mathrm{msec}$

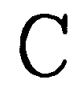

足

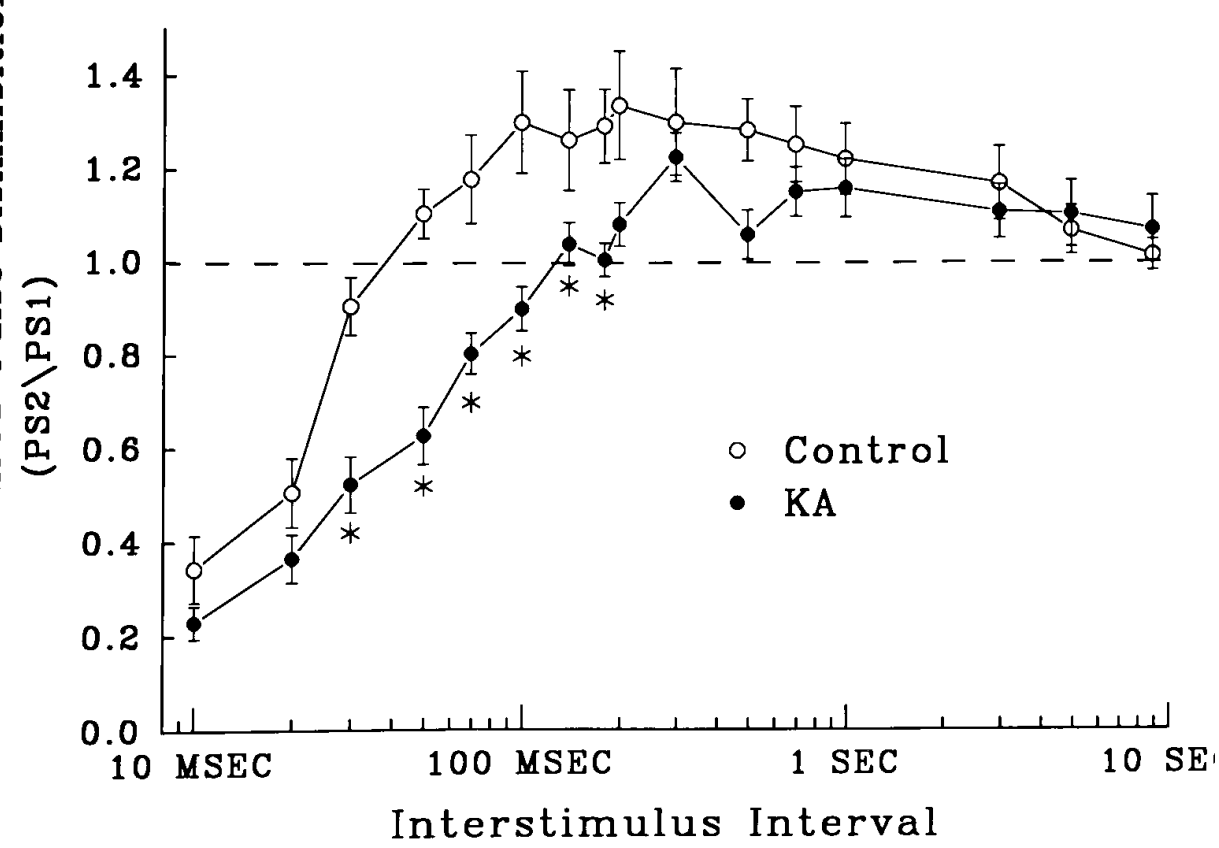

KA seizure-induced enhanced inhibition encompasses both early and late components of paired-pulse inhibition, suggesting that there is an increased postsynaptic activation of both $\mathrm{GABA}_{\mathrm{A}}$ and $\mathrm{GABA}_{\mathrm{B}}$ receptors.

We assessed the relative involvement of $\mathrm{GABA}_{\mathrm{A}}$ and $\mathrm{GABA}_{\mathrm{B}}$ inhibition and paired-pulse facilitation in enhanced inhibition by the selective removal of the early inhibitory component. Blockade of $\mathrm{GABA}_{\mathrm{A}}$ inhibition with bicuculline unmasked paired-pulse facilitation (Steffensen and Henriksen, 1991) in both controls and KA-treated rats. Because paired-pulse modulation represents the summation of inhibition and facilitation, the apparent enhancement of inhibition also could be attributable to a decrease of paired-pulse facilitation. Facilitation, produced by accumulation of $\mathrm{Ca}^{2+}$ in presynaptic terminals (Zucker, 1993) or NMDA receptor activation (Joy and Albertson, 1993), has a time course consistent with the apparent enhancement of inhibition after seizures. However, our data show that paired-pulse facilitation was not different after KA seizures and, therefore, did not contribute to enhanced inhibition. Because bicuculline blocked only the early component of seizure-enhanced inhibition, while not affecting the late phase, we conclude that enhanced inhibition after KA seizures consists of increases in postsynaptic responses of both $\mathrm{GABA}_{\mathrm{A}}$ and $\mathrm{GABA}_{\mathrm{B}}$ receptors, and not a decrease in facilitation or granule cell excitability.

The differences in $\mathrm{GABA}_{\mathrm{A}}$ and $\mathrm{GABA}_{\mathrm{B}}$ receptor structure (Barnard et al., 1992; Kuriyama et al., 1993; Stephenson, 1995) and signal transduction mechanisms (Alger and Nicoll, 1982; Schofield et al., 1987; Dutar and Nicoll, 1988) make it less likely that the enhancement of both responses is attributable to a single postsynaptic modification. A simpler hypothesis is that inhibitory output of GABAergic interneurons is increased after KA seizures, producing enhanced levels of synaptic GABA release that 


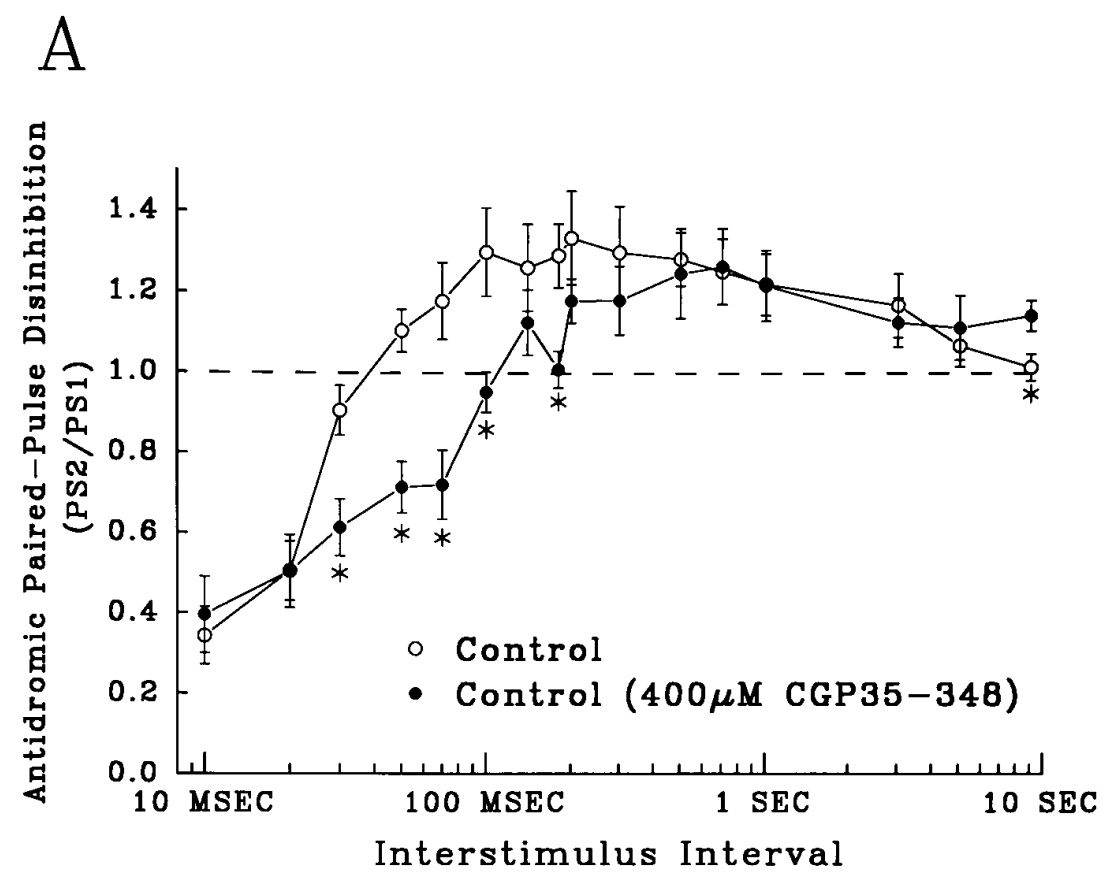

B

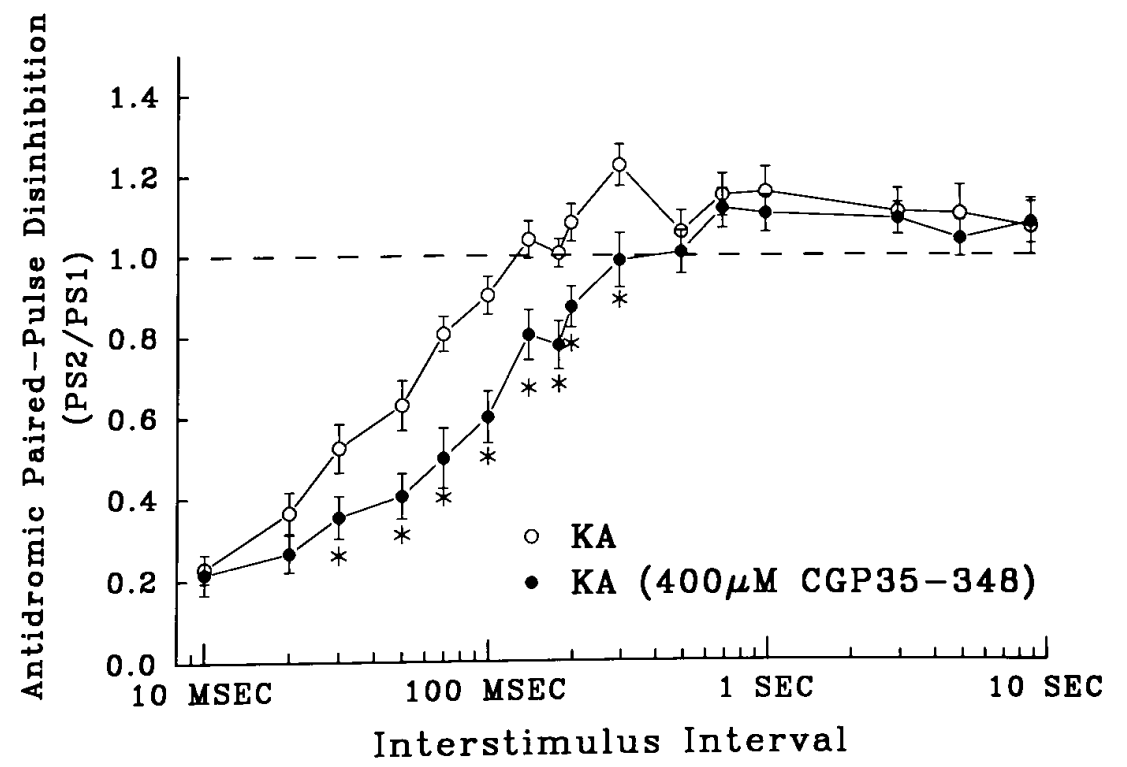

Figure 6. The $\mathrm{GABA}_{\mathrm{B}}$ receptor antagonist CGP 35348 $(400 \mu \mathrm{M})$ reduced an early component of disinhibition. $A$, Control recurrent disinhibition (open circles, $n=17$ ) and disinhibition in slices perfused in CGP 35348 (closed circles, $n=12$ ). An early component of disinhibition in control slices (30-120 msec) was blocked by CGP 35348 (asterisks, $p<0.05$ ). B, Disinhibition of recurrent inhibition in slices from KA-treated rats (open circles, $n=$ 20) and disinhibition in slices from KA-treated rats in the presence of CGP 35348 (closed circles, $n=18$ ). Slices from KA-treated rats also show a significant reduction in disinhibition at intervals of 30-120 msec (asterisks, $p<0.05)$. act indiscriminately on both $\mathrm{GABA}_{\mathrm{A}}$ and $\mathrm{GABA}_{\mathrm{B}}$ receptors. This hypothesis is supported by our data using the $\mathrm{GABA}_{\mathrm{B}}$ antagonist CGP 35348. Although a blocker of postsynaptic $\mathrm{GABA}_{\mathrm{B}}$ receptors on granule cells would be expected to remove late pairedpulse inhibition selectively, CGP 35348 increased equally both early and late inhibition. These results demonstrate that CGP 35348 blocks $\mathrm{GABA}_{\mathrm{B}}$ receptors that normally suppress GABA release. The similarity in time course of CGP 35348- and KA seizure-induced enhancement of inhibition, as well as the relative ineffectiveness of CGP 35348 to enhance inhibition further in slices from KA-treated rats, suggests that both treatments alter inhibition through the same mechanism, i.e., a reduction in functional activation of $\mathrm{GABA}_{\mathrm{B}}$ receptors presynaptic to granule neurons.
Presynaptic $\mathrm{GABA}_{\mathrm{B}}$ receptors have been shown to be responsible, in part, for the suppression of IPSPs during repeated stimulation, a phenomenon called disinhibition (Deisz and Prince, 1989; Thompson and Gahwiler, 1989; Brucato et al., 1992; Mott et al., 1993; Lambert and Wilson, 1994; Olpe et al., 1994). The involvement of a population of $\mathrm{GABA}_{\mathrm{B}}$ receptors that regulates GABA release is supported further by our finding that a CGP 35348-sensitive component of disinhibition of recurrent inhibition is decreased after KA status. Disinhibition in slices from KA status rats and control slices treated with CGP 35348 was decreased significantly at ISIs from 30 to $180 \mathrm{msec}$, whereas disinhibition at longer intervals was unaltered. The selective loss of an early component of disinhibition by the downregulation of mechanisms that suppress GABA release would lead to greater than 
A

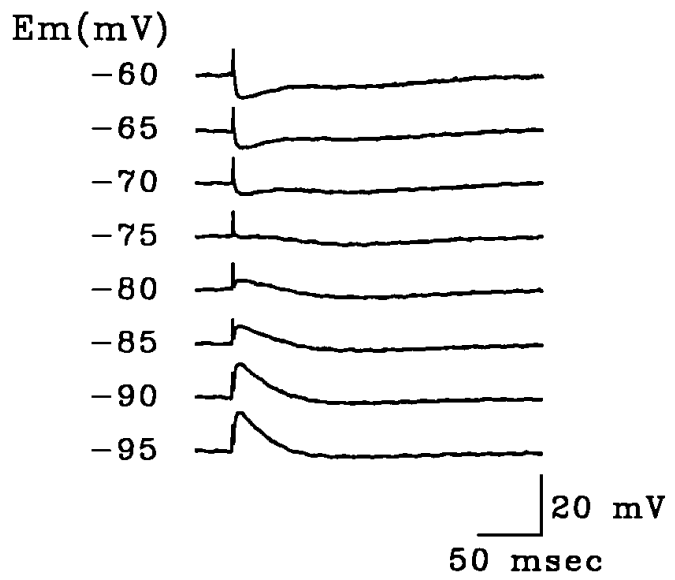

$\mathrm{B}$

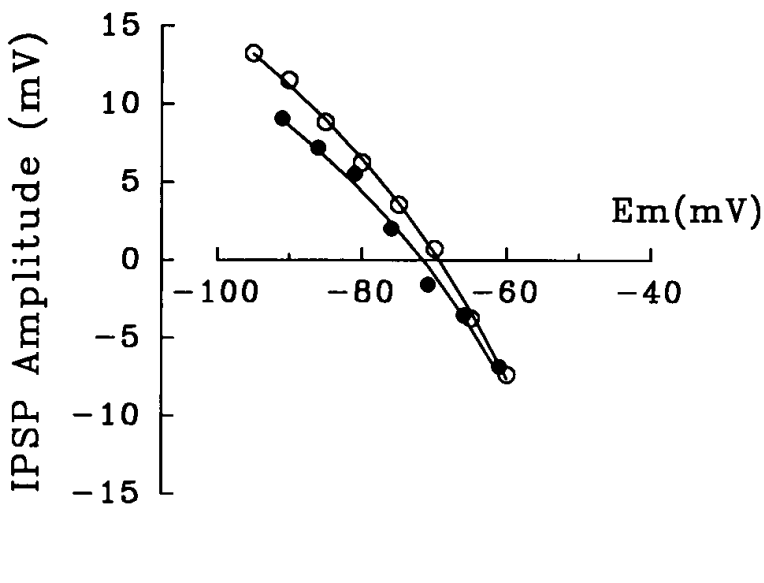

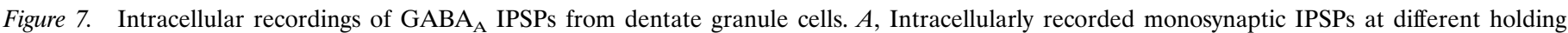
potentials induced by proximal stimulation of the stratum granulosum in the presence CNQX $(10 \mu \mathrm{M})$ and D-APV $(40 \mu \mathrm{M})$. The early component reversed at $-75 \mathrm{mV}$ and was blocked completely by bicuculline $(10 \mu \mathrm{M})$. $B$. The amplitude of $\mathrm{GABA}_{\mathrm{A}}$ IPSPs at various holding potentials from two representative cells, control (open circles) and after KA-induced status epilepticus (closed circles). Although current clamp recording precluded direct comparison, IPSP amplitudes were consistently similar between groups.

normal GABA output and enhanced postsynaptic inhibition. The ability of CGP 35348 to further reduce disinhibition in slices from KA-treated rats, but to a lesser extent than controls, demonstrates that although $\mathrm{GABA}_{\mathrm{B}}$ autoreceptor function may be downregulated, it was not completely absent. The effects of KA seizures and CGP 35348 support the theory that there are at least two components to disinhibition, one seizure- and CGP 35348-sensitive, at ISIs shorter than $200 \mathrm{msec}$, and one seizure- and CGP 35348insensitive, at intervals longer than $200 \mathrm{msec}$ (Lambert and Wilson, 1994; Olpe et al., 1994). The lack of CGP 35348- or KAinduced reduction in disinhibition at ISIs of 10-20 msec may suggest that an alternative mechanism underlies enhanced inhibition at short intervals.

There are three $\mathrm{GABA}_{\mathrm{B}}$ receptor populations presynaptic to granule neurons in the polysynaptic feedback inhibitory circuit that could control disinhibition and for which downregulation would enhance inhibition: (1) autoreceptors on GABAergic terminals synapsing directly on granule cells (Davies et al., 1990; Mott et al., 1993), (2) presynaptic receptors on glutamatergic terminals, which synapse on inhibitory interneurons (Collins et al., 1982), and (3) somatic or dendritic receptors directly on inhibitory interneurons (Misgeld et al., 1989). In the hippocampus, the release of both GABA (Davies et al., 1990; Mott et al., 1993) and glutamate (Harrison et al., 1990) has been shown to be suppressed by the activation of $\mathrm{GABA}_{\mathrm{B}}$ receptors on presynaptic terminals. Our finding that paired monosynaptic IPSPs did not show a decrease in disinhibition after KA status discounts a role for autoreceptors on the presynaptic GABAergic terminals synapsing directly on granule neurons. In contrast, Buhl et al. (1996) have reported recently that kindling did produce a decrease in disinhibition of monosynaptic $\mathrm{GABA}_{\mathrm{B}}$-mediated IPSCs in granule cells, suggesting that altered $\mathrm{GABA}_{\mathrm{B}}$ autoreceptor function may contribute to enhanced inhibition in kindled seizures.

Although $\mathrm{GABA}_{\mathrm{B}}$ autoreceptors directly presynaptic to granule cells have been shown to be involved in disinhibition, other $\mathrm{GABA}_{\mathrm{B}}$ receptor populations in the polysynaptic inhibitory path- way also mediate frequency-dependent suppression of inhibition. For example, the $\mathrm{GABA}_{\mathrm{B}}$ agonist baclofen depresses polysynaptic IPSPs to a greater extent than monosynaptically evoked IPSPs (Mott et al., 1993). GABA release from interneurons synapsing on granule cells can be modulated by $\mathrm{GABA}_{\mathrm{B}}$ receptors at excitatory and inhibitory inputs to these interneurons. In the polysynaptic recurrent inhibitory circuit, mossy fiber collaterals either directly activate inhibitory interneurons or activate glutamatergic mossy cells, which then drive the interneurons. Activation of presynaptic $\mathrm{GABA}_{\mathrm{B}}$ receptors on mossy fiber terminals or axonal terminals of mossy cells would suppress glutamate release and, therefore, decrease excitation of inhibitory interneurons (Collins et al., 1982). A decrease of these presynaptic $\mathrm{GABA}_{\mathrm{B}}$ receptors on glutamate terminals would allow more glutamate release and heightened activation of interneurons. Such an increase in excitatory activation of inhibitory interneurons has also been demonstrated after kindling (Buhl et al., 1996). However, Misgeld et al. (1989) found that the $\mathrm{GABA}_{\mathrm{B}}$ agonist baclofen did not effect mossy fiber-evoked EPSPs in hilar inhibitory interneurons, suggesting an absence of $\mathrm{GABA}_{\mathrm{B}}$ receptors on these glutamatergic synapses. Interneuron excitability also is controlled by GABAergic synapses from other inhibitory neurons (Scharfman et al., 1990). $\mathrm{GABA}_{\mathrm{B}}$ agonists hyperpolarize hilar interneurons, which mediate recurrent inhibition in granule cells (Misgeld et al., 1989). Thus, it is possible that downregulation of postsynaptic $\mathrm{GABA}_{\mathrm{B}}$ receptors on interneurons mediates the KA-induced loss of disinhibition and enhanced paired-pulse inhibition.

In conclusion, our data indicate that the mechanism for seizureinduced enhancement of dentate inhibition is, at least in part, through downregulation of $\mathrm{GABA}_{\mathrm{B}}$ receptors in the polysynaptic recurrent inhibitory circuit. These $\mathrm{GABA}_{\mathrm{B}}$ receptors normally cause suppression of GABAergic transmission, or disinhibition, with repetitive stimulation. Downregulation of a single receptor population could be induced rapidly, consistent with the time course of the appearance of enhanced inhibition, and would not require slower mechanisms such as sprouting and synaptogenesis. 
A

\section{Control}

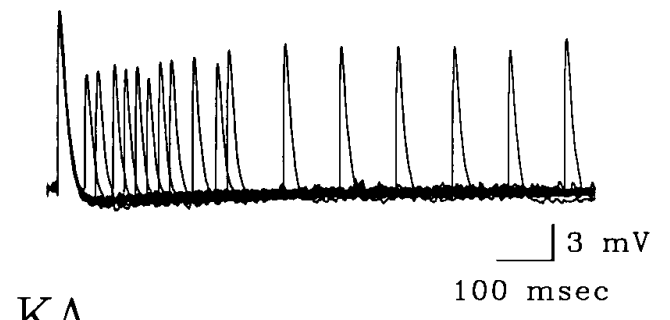

$\mathrm{KA}$

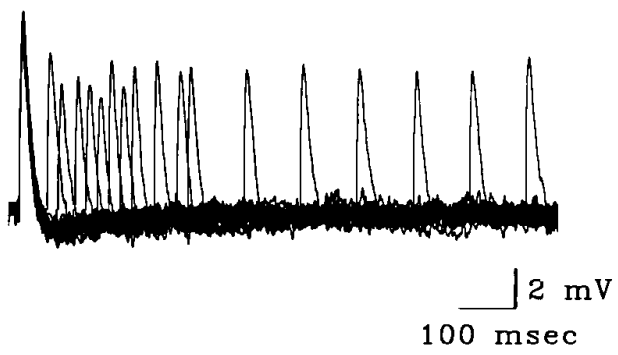

$\mathrm{B}$

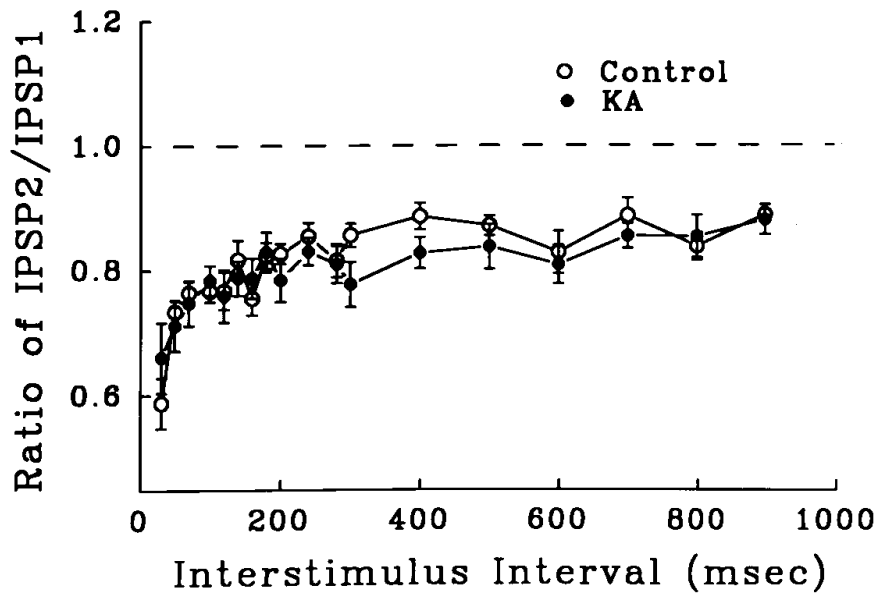

Figure 8. Disinhibition of monosynaptic IPSPs in dentate granule cells (holding potential $=-100 \mathrm{mV}$ ). $A$, Overlaid traces from 17 pairedpulse trials with ISIs ranging from 50 to $900 \mathrm{msec}$. The amplitude of the second IPSP was depressed compared with the first at all ISIs in slices from control and KA-treated rats. Seven-point smoothing was done to limit noise for overlaying traces. $B$, Paired-pulse profile of suppression of monosynaptic IPSPs at ISIs ranging from $30 \mathrm{msec}$ to $9 \mathrm{sec}$. There was no significant difference in the monosynaptic disinhibition between controls (open circles, $n=9$ ) and slices from KA-treated rats (closed circles, $n=13)$.

Such a mechanism would be well suited to enhance both early and late inhibition during trains of inputs, as might be produced in a hyperexcitable, epileptic circuit. Because enhanced inhibition develops while other seizure-induced alterations promote excitabil- ity elsewhere in the hippocampus, this may be an important compensatory mechanism in limiting seizure spread.

\section{REFERENCES}

Alger BE, Nicoll RA (1982) Feed-forward dendritic inhibition in rat hippocampal pyramidal cells studied in vitro. J Physiol (Lond) 328:105-123.

Barnard EA, Bateson AN, Darlison MG, Glencorse TA, Harvey RJ, Hicks AA, Lasham A, Shingai R, Usherwood PN, Vreugdenhil El (1992) Genes for the $\mathrm{GABA}_{\mathrm{A}}$ receptor subunit types and their expression. Adv Biochem Psychopharmacol 47:17-27.

Bekenstein J, Rempe D, Lothman E (1993) Decreased heterosynaptic and homosynaptic paired pulse inhibition in the rat hippocampus as a chronic sequela to limbic status epilepticus. Brain Res 601:111-120.

Buhl EH, Otis TS, Mody I (1996) Zinc-induced collapse of augmented inhibition by GABA in a temporal lobe epilepsy model. Science 271:369-373.

Brucato FH, Morrisett RA, Wilson WA, Swartzwelder HS (1992) The $\mathrm{GABA}_{\mathrm{B}}$ receptor antagonist, CGP-35348, inhibits paired-pulse disinhibition in the rat dentate gyrus in vivo. Brain Res 588:150-153.

Brunner H, Misgeld U (1993) Synaptic activation in guinea-pig dentate area: dependence on the stimulation site. Pflügers Arch 423:497-503.

Cavazos JE, Golarai G, Sutula TP (1991) Mossy fiber synaptic reorganization induced by kindling: time course of development, progression, and permanence. J Neurosci 11:2795-2803.

Cavazos JE, Sutula TP (1990) Progressive neuronal loss induced by kindling: a possible mechanism for mossy fiber synaptic reorganization and hippocampal sclerosis. Brain Res 527:1-6.

Collins GG, Anson J, Kelly EP (1982) Baclofen: effects on evoked field potentials and amino acid neurotransmitter release in the rat olfactory cortex slice. Brain Res 238:371-383.

Cronin J, Obenaus A, Houser CR, Dudek FE (1992) Electrophysiology of dentate granule cells after kainate-induced synaptic reorganization of the mossy fibers. Brain Res 573:305-310.

Davies CH, Collingridge GL (1993) The physiological regulation of synaptic inhibition by $\mathrm{GABA}_{\mathrm{B}}$ autoreceptors in rat hippocampus. J Physiol (Lond) 472:245-265.

Davies CH, Davies SN, Collingridge GL (1990) Paired-pulse depression of monosynaptic GABA-mediated inhibitory postsynaptic responses in rat hippocampus. J Physiol (Lond) 424:513-531.

Davies CH, Pozza MF, Collingridge GL (1993) CGP 55845A: a potent antagonist of $\mathrm{GABA}_{\mathrm{B}}$ receptors in the $\mathrm{CA} 1$ region of rat hippocampus. Neuropharmacology 32:1071-1073.

de Jonge M, Racine RJ (1987) The development and decay of kindlinginduced increases in paired-pulse depression in the dentate gyrus. Brain Res 412:318-328.

Deisz RA, Prince DA (1989) Frequency-dependent depression of inhibition in guinea-pig neocortex in vitro by $\mathrm{GABA}_{\mathrm{B}}$ receptor feed-back on GABA release. J Physiol (Lond) 412:513-541.

Dutar P, Nicoll RA (1988) A physiological role for $\mathrm{GABA}_{\mathrm{B}}$ receptors in the central nervous system. Nature 332:156-158.

Gilbert ME (1991) Potentiation of inhibition with perforant path kindling: an NMDA-receptor dependent process. Brain Res 564:109-116.

Goddard GV, McIntyre DC, Leech CK (1969) A permanent change in brain function resulting from daily electrical stimulation. Exp Neurol 25:295-330.

Haas HL, Schaerer B, Vosmansky H (1979) A simple perfusion chamber for the study of nervous tissue slices in vitro. J Neurosci Methods $1: 323-325$.

Haas KZ, Stanton PK, Moshé SL (1994) Contribution of GABA ${ }_{A}$ and $\mathrm{GABA}_{\mathrm{B}}$ receptors to enhanced dentate paired-pulse inhibition following kainic acid seizures. Soc Neurosci Abstr 20:408.

Harrison NL, Lovinge DM, Lambert NA, Teyler TJ, Prager R, Ong J, Kerr DI (1990) The actions of 2-hydroxy-saclofen at presynaptic $\mathrm{GABA}_{\mathrm{B}}$ receptors in the rat hippocampus. Neurosci Lett 119:272-276.

Holmes GL, Thompson JL (1988) Effects of kainic acid on seizure susceptibility in the developing brain. Brain Res 467:51-59.

Holmes GL, Chronopoulos A, Stafstrom CE, Mikati MA, Thurber SJ, Hyde PA, Thompson JL (1993) Effects of kindling on subsequent learning, memory, behavior, and seizure susceptibility. Brain Res Dev Brain Res 73:71-77.

Joy RM, Albertson TE (1993) NMDA receptors have a dominant role in population spike-paired pulse facilitation in the dentate gyrus of urethane-anesthetized rats. Brain Res 604:273-282. 
Kapur J, Michelson HB, Buterbaugh GG, Lothman EW (1989) Evidence for a chronic loss of inhibition in the hippocampus after kindling: electrophysiological studies. Epilepsy Res 4:90-99.

King GL, Dingledine R, Giacchino JL, McNamara JO (1985) Abnormal neuronal excitability in hippocampal slices from kindled rats. J Neurophysiol 54:1295-1304.

Kohr G, De Koninck Y, Mody I (1993) Properties of NMDA receptor channels in neurons acutely isolated from epileptic (kindled) rats. J Neurosci 13:3612-3627.

Kohr G, Mody I (1994) Kindling increases $N$-methyl-D-aspartate potency at single $N$-methyl-D-aspartate channels in dentate gyrus granule cells. Neuroscience 62:975-981.

Kuriyama K, Hirouchi M, Nakayasu H (1993) Structure and function of cerebral $\mathrm{GABA}_{\mathrm{A}}$ and $\mathrm{GABA}_{\mathrm{B}}$ receptors. Neurosci Res 17:91-99.

Lambert NA, Wilson WA (1993) Discrimination of post- and presynaptic $\mathrm{GABA}_{\mathrm{B}}$ receptor-mediated responses by tetrahydroaminoacridine in area CA3 of the rat hippocampus. J Neurophysiol 69:630-635.

Lambert NA, Wilson WA (1994) Temporally distinct mechanisms of use-dependent depression at inhibitory synapses in the rat hippocampus in vitro. J Neurophysiol 72:121-130.

Lothman EW, Bertram III EH (1993) Epileptogenic effects of status epilepticus. Epilepsia 34:S59-S70.

Martin D, McNamara JO, Nadler JV (1992) Kindling enhances sensitivity of CA3 hippocampal pyramidal cells to NMDA. J Neurosci 12:1928-1935.

Maru E, Goddard GV (1987) Alteration in dentate neuronal activities associated with perforant path kindling. III. Enhancement of synaptic inhibition. Exp Neurol 96:46-60.

Mello LE, Cavalheiro EA, Tan AM, Kupfer WR, Pretorius JK, Babb TL, Finch DM (1993) Circuit mechanisms of seizures in the pilocarpine model of chronic epilepsy: cell loss and mossy fiber sprouting. Epilepsia 34:985-995.

Milgram NW, Yearwood T, Khurgel M, Ivy GO, Racine R (1991) Changes in inhibitory processes in the hippocampus following recurrent seizures induced by systemic administration of kainic acid. Brain Res 551:236-246.

Milgram NW, Michael M, Cammisuli S, Head E, Ferbinteanu J, Reid C, Murphy MP, Racine R (1995) Development of spontaneous seizures over extended electrical kindling. II. Persistence of dentate inhibitory suppression. Brain Res 670:112-120.

Misgeld U, Muller W, Brunner H (1989) Effects of (-)baclofen on inhibitory neurons in the guinea pig hippocampal slice. Pflügers Arch 414:139-144.

Mody I, Stanton PK, Heinemann U (1988) Activation of $N$-methyl-Daspartate receptors parallels changes in cellular and synaptic properties of dentate gyrus granule cells after kindling. J Neurophysiol 59:1033-1054.

Mott DD, Xie CW, Wilson WA, Swartzwelder HS, Lewis DV (1993) $\mathrm{GABA}_{\mathrm{B}}$ autoreceptors mediate activity-dependent disinhibition and enhance signal transmission in the dentate gyrus. J Neurophysiol 69:674-691.

Okazaki MM, Evenson DA, Nadler JV (1995) Hippocampal mossy fiber sprouting and synapse formation after status epilepticus in rats: visualization after retrograde transport of biocytin. J Comp Neurol 352:515-534.

Oliver MW, Miller JJ (1985) Alterations of inhibitory processes in the dentate gyrus following kindling-induced epilepsy. Exp Brain Res $57: 443-447$.

Olpe HR, Karlsson G, Pozza MF, Brugger F, Steinmann M, Van Riezen H, Fagg G, Hall RG, Froestl W, Bittiger H (1990) CGP 35348: a centrally active blocker of $\mathrm{GABA}_{\mathrm{B}}$ receptors. Eur $\mathrm{J}$ Pharmacol 187:27-38.

Olpe HR, Steinmann MW, Greiner K,Pozza MF (1994) Contribution of presynaptic GABA-B receptors to paired-pulse depression of GABAresponses in the hippocampus. Naunyn Schmiedebergs Arch Pharmacol 349:473-477.
Otis TS, De Koninck Y, Mody I (1994) Lasting potentiation of inhibition is associated with an increased number of gamma-aminobutyric acid type A receptors activated during miniature inhibitory postsynaptic currents. Proc Natl Acad Sci USA 91:7698-7702.

Pearce RA, Grunder SD, Faucher LD (1995) Different mechanisms for use-dependent depression of two $\mathrm{GABA}_{\mathrm{A}}$-mediated IPSCs in rat hippocampus. J Physiol (Lond) 484:425-435.

Pitler TA, Alger BE (1994) Differences between presynaptic and postsynaptic $\mathrm{GABA}_{\mathrm{B}}$ mechanisms in rat hippocampal pyramidal cells. J Neurophysiol 72:2317-2327.

Represa A, Jorquera I, Le Gal La Salle G, Ben-Ari Y (1993) Epilepsy induced collateral sprouting of hippocampal mossy fibers: does it induce the development of ectopic synapses with granule cell dendrites? Hippocampus 3:257-268.

Scanziani M, Capogna M, Gahwiler BH, Thompson SM (1992) Presynaptic inhibition of miniature excitatory synaptic currents by baclofen and adenosine in the hippocampus. Neuron 9:919-927.

Scharfman HE, Kunkel DD, Schwartzkroin PA (1990) Synaptic connections of dentate granule cells and hilar neurons: results of paired intracellular recordings and intracellular horseradish peroxidase injections. Neuroscience 37:693-707.

Schofield PR, Darlison MG, Fujita N, Burt DR, Stephenson FA, Rodriguez H, Rhee LM, Ramachandran J, Reale V, Glencorse TA (1987) Sequence and functional expression of the GABA A receptor shows a ligand-gated receptor super-family. Nature 328:221-227.

Sloviter RS (1987) Decreased hippocampal inhibition and a selective loss of interneurons in experimental epilepsy. Science 235:73-76.

Sloviter RS (1992) Possible functional consequences of synaptic reorganization in the dentate gyrus of kainate-treated rats. Neurosci Lett 137:91-96.

Sperber EF, Haas KZ, Stanton PK, Moshé SL (1991) Resistance of the immature hippocampus to seizure-induced synaptic reorganization. Brain Res Devel Brain Res 60:88-93.

Spiller AE, Racine RJ (1994) The effect of kindling beyond the "stage 5" criterion on paired-pulse depression and hilar cell counts in the dentate gyrus. Brain Res 635:139-147.

Stafstrom CE, Thompson JL, Holmes GL (1992) Kainic acid seizures in the developing brain: status epilepticus and spontaneous recurrent seizures. Brain Res Devel Brain Res 65:227-236.

Steffensen SC, Henriksen SJ (1991) Effects of baclofen and bicuculline on inhibition in the fascia dentata and hippocampus region superior. Brain Res 538:46-53.

Stephenson FA (1995) The GABA ${ }_{A}$ receptors. Biochem J 310:1-9.

Sutula T, He XX, Cavazos J, Scott G (1988) Synaptic reorganization in the hippocampus induced by abnormal functional activity. Science 239:1147-1150.

Tauck DL, Nadler JV (1985) Evidence of functional mossy fiber sprouting in hippocampal formation of kainic acid-treated rats. J Neurosci 5:1016-1022.

Thompson SM, Gahwiler BH (1989) Activity-dependent disinhibition. III. Desensitization and $\mathrm{GABA}_{\mathrm{B}}$ receptor-mediated presynaptic inhibition in the hippocampus in vitro. J Neurophysiol 61:524-533.

Thompson SM, Gahwiler BH (1992) Comparison of the actions of baclofen at pre- and postsynaptic receptors in the rat hippocampus in vitro. J Physiol (Lond) 451:329-345.

Tuff LP, Racine RJ, Adamec R (1983) The effects of kindling on GABAmediated inhibition in the dentate gyrus of the rat. I. Paired-pulse depression. Brain Res 277:79-90.

Wong BY, Moshé SL (1987) Mutual interactions between repeated flurothyl convulsions and electrical kindling. Epilepsy Res 1:159-164.

Zhao D, Leung LS (1992) Hippocampal kindling induced paired-pulse depression in the dentate gyrus and paired-pulse facilitation in CA3. Brain Res 582:163-167.

Zucker RS (1993) Calcium and transmitter release. J Physiol (Paris) $87: 25-36$. 